\title{
$\mathrm{RCP}$ 시나리오에 따른 미래 전지구 육상탄소순환 변화 전망
}

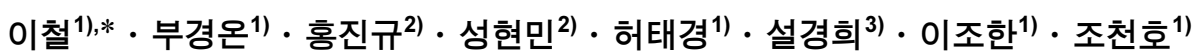 \\ 1)국립기상연구소, ${ }^{2}$ 연세대학교 대기과학과/생물대기연구실, ${ }^{3)}($ 재 ) 한국형수치예보모델개발사업단
}

(접수일: 2014년 3월 10일, 게재확정일: 2014년 5월 25일)

\section{Future Changes in Global Terrestrial Carbon Cycle under RCP Scenarios}

\author{
Cheol Lee ${ }^{1), *}$, Kyung-On Boo ${ }^{1)}$, Jinkyu Hong ${ }^{2)}$, Hyunmin Seong ${ }^{2)}$, Tae-kyung Heo ${ }^{1)}$, \\ Kyung-Hee Seol ${ }^{3)}$, Johan Lee ${ }^{1)}$, and ChunHo Cho ${ }^{1)}$ \\ ${ }^{1)}$ National Institute of Meteorological Research, Jeju, Korea \\ ${ }^{2)}$ Ecosystem-Atmosphere Process Lab., Department of Atmospheric Sciences, Seoul, Korea \\ ${ }^{3)}$ Korea Institute of Atmosphere Prediction Systems, Seoul, Korea
}

(Manuscript received 10 March 2014; accepted 25 May 2014)

\begin{abstract}
Terrestrial ecosystem plays the important role as carbon sink in the global carbon cycle. Understanding of interactions of terrestrial carbon cycle with climate is important for better prediction of future climate change. In this paper, terrestrial carbon cycle is investigated by Hadley Centre Global Environmental Model, version 2, Carbon Cycle (HadGEM2-CC) that considers vegetation dynamics and an interactive carbon cycle with climate. The simulation for future projection is based on the three (8.5/4.5/2.6) representative concentration pathways (RCPs) from 2006 to 2100 and compared with historical land carbon uptake from 1979 to 2005. Projected changes in ecological features such as production, respiration, net ecosystem exchange and climate condition show similar pattern in three RCPs, while the response amplitude in each RCPs are different. For all RCP scenarios, temperature and precipitation increase with rising of the atmospheric $\mathrm{CO}_{2}$. Such climate conditions are favorable for vegetation growth and extension, causing future increase of terrestrial carbon uptakes in all RCPs. At the end of 21 st century, the global average of gross and net primary productions and respiration increase in all RCPs and terrestrial ecosystem remains as carbon sink. This enhancement of land $\mathrm{CO}_{2}$ uptake is attributed by the vegetated area expansion, increasing LAI, and early onset of growing season. After mid-21st century, temperature rising leads to excessive increase of soil respiration than net primary production and thus the terrestrial carbon uptake begins to fall since that time. Regionally the NEE average value of East-Asia $\left(90^{\circ} \mathrm{E}-140^{\circ} \mathrm{E}, 20^{\circ} \mathrm{N} \sim 60^{\circ} \mathrm{N}\right)$ area is bigger than that of the same latitude band. In the end- $21^{\text {st }}$ the NEE mean values in East-

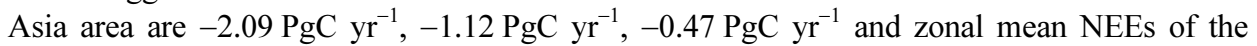

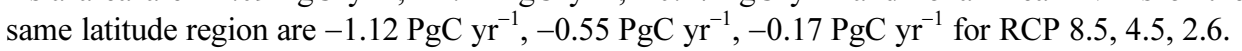

Key words: Terrestrial carbon cycle, climate change, RCP scenario, HadGEM2

\footnotetext{
*Corresponding Author: Cheol Lee, National Institute of Meteorological Research, 33 Seohobuk-ro, Seogwipo-si, JeJu-do 697-845, Korea.

Phone : +82-64-780-6672, Fax : +82-64-738-9072

E-mail : tetsulee83@korea.kr
} 
1. 서

과거 20 세기 동안 전 지구적으로 나타난 기후변화 의 주요한 원인 중 하나로 대기 중 $\mathrm{CO}_{2}$ 농도의 증가 를 언급할 수 있다(IPCC, 2007). 산업화 시대 이후 인 간활동으로 인해 증가된 대기 중 $\mathrm{CO}_{2}$ 는 기온과 강수 량을 변화시키고, 이렇게 달라진 기온과 강수량은 개 화시기, 재배기간, 생산량 등 육상 식생 성장환경에 다양한 영향을 주었다. 이러한 식생 성장 환경 변화 는 광합성 및 호흡을 통한 식생의 이산화탄소 흡수 능력을 변화시켜 다시 대기 중 이산화탄소 농도를 조 절하는 되먹임 작용을 수반하였다. 따라서 이러한 탄 소-기후-식생 상호 작용에 대한 이해는 현재 당면한 기후 변화를 보다 잘 이해하고, 기후 변화 예측의 불 확실성을 줄이는 데 있어 매우 필요하다. 보다 구체 적으로 그 동안 일어난 기후 변화와 대기 중 이산화 탄소 농도증가가 육상생태계의 이산화탄소 흡수량의 증가를 가져왔는지 이해함으로써, 미래 기후 변화에 따른 육상생태계의 이산화탄소 흡수 능력 변화와 기 후변화를 보다 정확하게 예측하는 데 매우 중요한 단 서를 제공할 수 있을 것이다. 그리고 육상생태계의 이 산화탄소 흡수 능력의 변화와 기후변화를 보다 정확 하게 예측하는 데 매우 중요한 단서를 제공할 수 있 을 것이고 이는 향후 이산화탄소 농도증가에 대한 기 후변화에 국가적으로 적합한 적응 및 저감 계획 수립 에 많은 도움을 줄 수 있을 것이다.

IPCC AR4 기술보고서(2007)에 따르면 1980년대 이 후 인위적으로 배출된 $\mathrm{CO}_{2}$ 의 $50 \%$ 가 육상생태계와 해 양의 자연적 흡수과정에 의해 제거되고 이 흡수능력 은 산림의 일차생산량과 산림 면적의 변화 등으로 달 라질 수 있다. 이와 관련하여 식생의 성장 증가와 대 기 중 이산화탄소 흡수 능력의 증가의 상관관계를 보 이는 다양한 연구 결과가 제시되었다(e.g., Mynenl et al., 1997; Fischer et al., 2007; Beck and Goetz, 2011; Port et al., 2012). Mynenl et al. (1997)과 Piao et al. (2011)은 위성자료 분석을 통하여 1981 1991년 북반 구 고위도 여름철 식생성장과 식생 생장기간이 길어 짐에 따른 광합성활동의 증가가 있음을 보였고, Jolly et al. (2005)은 고산지대인 알프스지역에서 식생의 성 장시기 및 식생면적 증가와 광합성 활동 강화가 있음 을 보고하였다. 그리고 Fischer et al. (2007)도 미국 중남부인 오클라호마 지역 초원의 성장시기가 증가함 을 보고하였다.

이러한 육상생태계 이산화탄소 흡수능력은 기후변 화에 의해 영향을 받는데, 1997년 이후 유라시아 고 위도지역에서 강수 감소에 따라 식생성장이 제한 받 고(Piao et al., 2011), 가뭄으로 인하여 식생의 순일차 생산량(Net Primary Productivity, NPP)이 감소되어 육
상생태계의 대기 중 이산화탄소 흡수역할이 감소된다 는 연구 보고도 있었다(Zhao and Running, 2010). 이 는 점차 가속화되는 기후변화 속에서 육상생태계가 흡수원으로 미래에도 지속될 것인지에 대한 관심을 모으게 되었다. 이와 관련하여 Shao et al. (2013)는 CMIP5 8개 모델자료로부터 21세기 말 육상생태계의 탄소흡수량이 증가하며 지역적으로 열대와 고위도지 역의 중요성을 전망하였다. 이외에도 Notaro et al. (2007), Liddicoat et al. (2013), Jones et al. (2013)에 서 미래 육상생태계의 대기 중 이산화탄소 흡수 능력 에 대한 관심과 논의가 다양하게 이루어졌다. 이에 선 행연구들을 토대로 본 연구에서는 미래 기후변화에 따른 육상생태계의 변화에 대한 이해를 높이고자 전 지구 기후예측 모형을 활용하여 $\mathrm{CO}_{2}$ 흡수와 배출에 대한 미래 육상생태계의 $\mathrm{CO}_{2}$ 순환분석을 하고자 한다.

\section{2. 연구방법}

본 연구에서는 영국기상청의 탄소순환이 접목된 HadGEM2-CC (Carbon Cycle)를 사용하였고(Coillins et al., 2011; Jones et al., 2011; Martin et al., 2011), 현재 및 대표농도경로(Representative Concentration Pathways, RCPs, Moss et al., 2010) 시나리오 3종 (RCP 2.6/4.5/8.5)에 대해 120년(1979 2099) 간의 미 래 장기 적분결과를 분석하였다. 모델 적분에 사용된 현재 및 대표농도경로 시나리오 3종(RCP 2.6/4.5/8.5) 및 HadGEM2-CC (Carbon Cycle)에 대해 살펴보면 다 음과 같다.

\subsection{RCPs}

4개의 시나리오로 알려진 대표농도경로(Representative Concentration Pathways, RCPs)에는 RCP 2.6 (Van Vuuren et al., 2007), RCP 4.5 (Clarke et al., 2007), RCP 6.0 (Hijioka et al., 2008), RCP 8.5 (Riahi et al., 2007)가 있다. RCP 시나리오의 숫자는 복사 강제력, 즉 온실가스 등으로 에너지의 평형을 변화시키는 영 향력의 정도를 의미하는 양으로서 단위는 $\mathrm{Wm}^{-2}$ 이고 지상에 도달되는 태양복사가 약 $238 \mathrm{Wm}^{-2}$ 이므로 $\mathrm{RCP}$ 2.6/4.5/6.0/8.5의 복사강제력은 지표면 입사 태양복사 량의 약 $1.1 \%, 1.9 \%, 2.5 \%, 3.6 \%$ 에 해당된다. $\mathrm{RCP}$ 2.6 은 강력한 탄소절감정책이 사용된 시나리오로서 화 석연료에 의존하는 많은 에너지를 바이오 에너지로 대체시키기 위해 농경지(초지, 농작물)가 많이 증가한 다. RCP 4.5 및 6.0 은 대표적인 중간 시나리오이며 탄소절감정책이 실현되는 시나리오이다. 모두 $\mathrm{RCP}$ 2.6보다 약간 더 많은 에너지를 사용하는데 RCP 6.0 은 화석연료의 사용 경향이 있는 반면 RCP 4.5는 청 정 에너지원과 탄소 포집 및 저장의 일부 사용을 특 


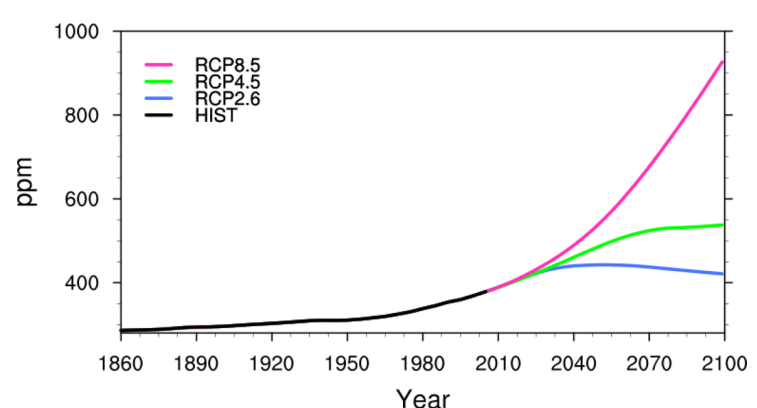

Fig. 1. Atmospheric $\mathrm{CO}_{2}$ concentration (ppm) used in this study.

징으로, RCP 6.0 에 비하여 화석 연료에 덜 의존한다. $\mathrm{RCP}$ 8.5는 탄소절감정책을 사용하지 않고 현재처럼 산업활동을 계속 이어가는 시나리오이며, 높은 인구 성장률과 기술발전을 가정하므로 $\mathrm{RCP}$ 시나리오 중에 서 가장 많은 에너지가 집중되어 $\mathrm{CO}_{2}$ 의 방출량이 가 장 많다. 그리고 화석연료가 에너지원으로 쓰이고 높 은 인구증가율을 뒷받침하기 위해 식량 생산량이 증 가하는 시나리오이다.

\section{2 모델}

본 연구에서는 영국 기상청의 탄소순환이 접목된 HadGEM2-CC (Carbon Cycle)을 사용하였다(Collins et al., 2011; Jones et al., 2011; Martin et al., 2011). $\mathrm{CO}_{2}$ 농도는 1860 년부터 미래 2100년까지 4개의 시나리오 에 대해 서로 다른 값을 사용하였다(Fig. 1). 대기모델 의 수평격자는 $1.875^{\circ} \times 1.25^{\circ}$ 로 이루어져있으며 연직 격자는 38 층, 모델 고도는 약 $40 \mathrm{~km}$ 로 구성되어 있다. 해양모델의 수평격자는 $1^{\circ} \times 1 / 3^{\circ} \sim 1^{\circ}$ 로 이루어져 있으 며 연직격자는 40 층으로 구성되어 있다. 식생분포는 역학적 식생모형인 TRIFFID (Top-down Representation of Interactive Foliage and Flora Including Dynamics) 에서 모의된다(Cox, 2001). TRIFFID 식생모형은 LotkaVolterra 미분방정식을 사용하여 활엽수, 침엽수, $\mathrm{C} 3$ 초지, $\mathrm{C} 4$ 초지, 관목의 5 개 자연 식생의 경쟁을 수치 모의한다. 토양수분, 빛, 그리고 대기 중 $\mathrm{CO}_{2}$ 농도를 고려하여 계산된 식생의 순일차생산량은 지면모델 MOSES2 (Met Office Surface Exchange Scheme, version 2, Essery et al., 2001)에서 계산한다.

한편 인간의 활동에 따른 경작지 및 목초지 변화는 Jones et al. $(2011,2013)$ 을 따라 각 시나리오마다 다 르게 처방하였다(Fig. 2). 농경지 면적은 $\mathrm{C} 3$ 초지와 $\mathrm{C} 4$ 초지 면적을 합한 값으로 사용되며 그 성장률은 $\mathrm{RCP}$ 시나리오에 따라 결정된다. RCP 2.6/8.5 시나리 오에서는 농경지의 면적이 21세기 동안 증가하며, $\mathrm{RCP}$ 4.5 시나리오에서는 감소한다. 그리고 HadGEM2-CC

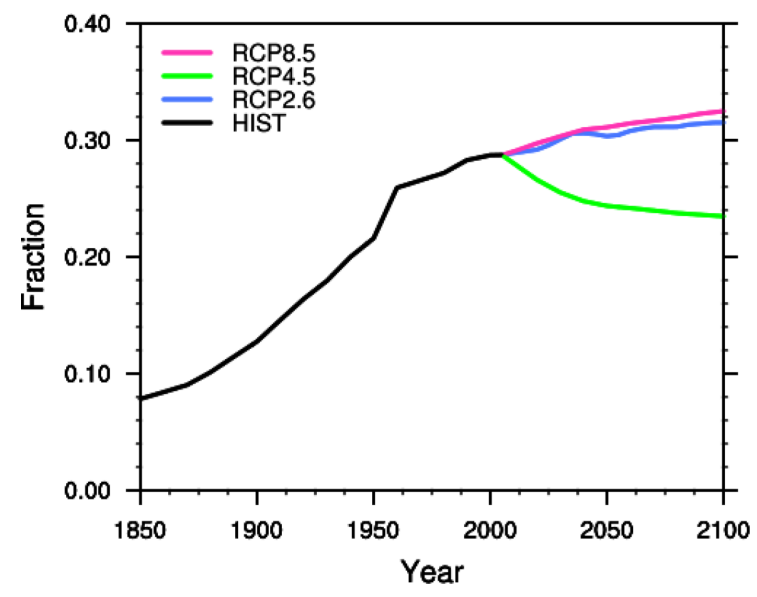

Fig. 2. Fractional coverage of global land surface devoted to agriculture in this study.

모형은 농경지대에서 나무(활엽수, 침엽수)와 관목이 자라는 것을 제한하였다(Collins et al., 2011).

\section{3. 실험결과}

\subsection{RCPs 에 따른 기온, 강수와 식생 변화 전망}

$\mathrm{RCP}$ 시나리오별로 $\mathrm{CO}_{2}$ 농도를 살펴보면(Fig. 1) 1950 년대까지는 완만하게 증가하다가 그 이후에 급격 하게 증가하는 것을 볼 수 있다. 탄소배출이 가장 적 은 RCP 2.6 시나리오는 2000년대 중반에 $442 \mathrm{ppm}$ 까 지 증가하였다가 완만하게 감소하는 모습이 보인다. 중간 시나리오인 RCP 4.5 시나리오에서는 2000년대 후반에 농도 증가가 둔화되고 탄소배출이 가장 많은 $\mathrm{RCP} 8.5$ 시나리오는 2100 년까지 급격하게 증가한다. 2100 년에 RCP 2.6은 $420 \mathrm{ppm}, \mathrm{RCP} 4.5$ 는 $538 \mathrm{ppm}$, $\mathrm{RCP}$ 8.5는 $935 \mathrm{ppm}$ 이다. 이러한 대기 중 이산화탄소 증가에 대해 RCP 2.6 시나리오에서는 21세기 말 (2075 2099년)에 전지구 평균 기온상승폭이 20세기 말(1981 2005년)에 비해 약 $1.6^{\circ} \mathrm{C}$ 상승을 전망한다 (Fig. 3a). 이는 같은 시나리오에서 2000년대 중반에 $2.04^{\circ} \mathrm{C}$ 기온 상승을 예측한 Liddicoat et al. (2013)의 연구 결과와 유사하다. RCP 4.5와 RCP 8.5 시나리오 에서는 전 지구 평균기온 상승이 2100 년에 각각 $2.6^{\circ} \mathrm{C}$ 와 $4.5^{\circ} \mathrm{C}$ 증가하였다. 이 또한 Rogelj et al. (2012)와 Knutti et al. (2012), Xu et al. (2012)에서의 기온 상 승 결과와 유사하다.

기온상승과 더불어 전 지구 연평균 강수량 역시 $\mathrm{RCP}$ 시나리오별로 21세기 말 증가가 전망된다(Fig. 3b). 1986 2005년 동안의 평균 강수량에 대한 21세기 말 강수량 증가율은 Baek et al. (2013)이 탄소모형이 제외된 대기-해양 접합 모형인 HadGEM2-AO 실험 결 
(a)

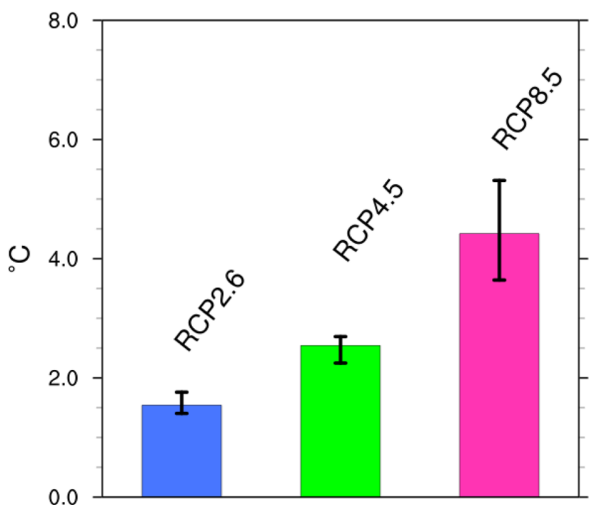

(b)

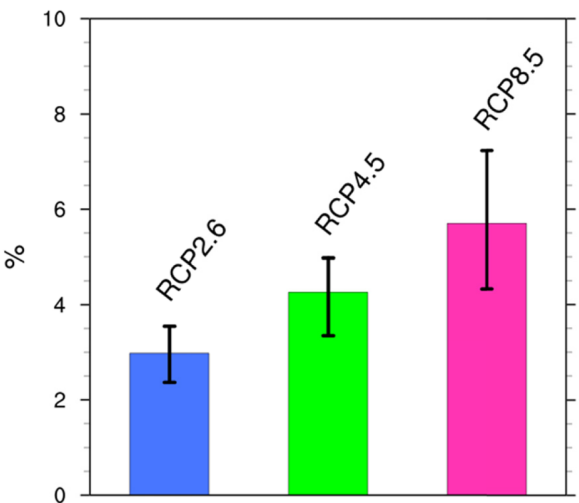

Fig. 3. Global mean temperature $\left({ }^{\circ} \mathrm{C}\right)$ changes and precipitation changes $(\%)$ over the period of 2075 2099 minus 1981 2005. Black line is standard deviation of annual mean values.

과 분석을 통해 $\mathrm{RCP} 2.6$ 은 $2.1 \%$, $\mathrm{RCP} 4.5$ 는 $4.0 \%$, $\mathrm{RCP} 6.0$ 은 $4.6 \%, \mathrm{RCP} 8.5$ 는 $4.6 \%$ 증가하는 것으로 보고하였다. 이는 기온이 증가함에 따라 증발량이 많
아지고, 이에 따라 강수도 함께 증가하는 것으로 판 단된다. 이에 비해, 탄소모형이 접합된 HadGEM2-CC 를 이용한 본 연구에서는 RCP 2.6 은 $2.9 \%, \mathrm{RCP} 4.5$
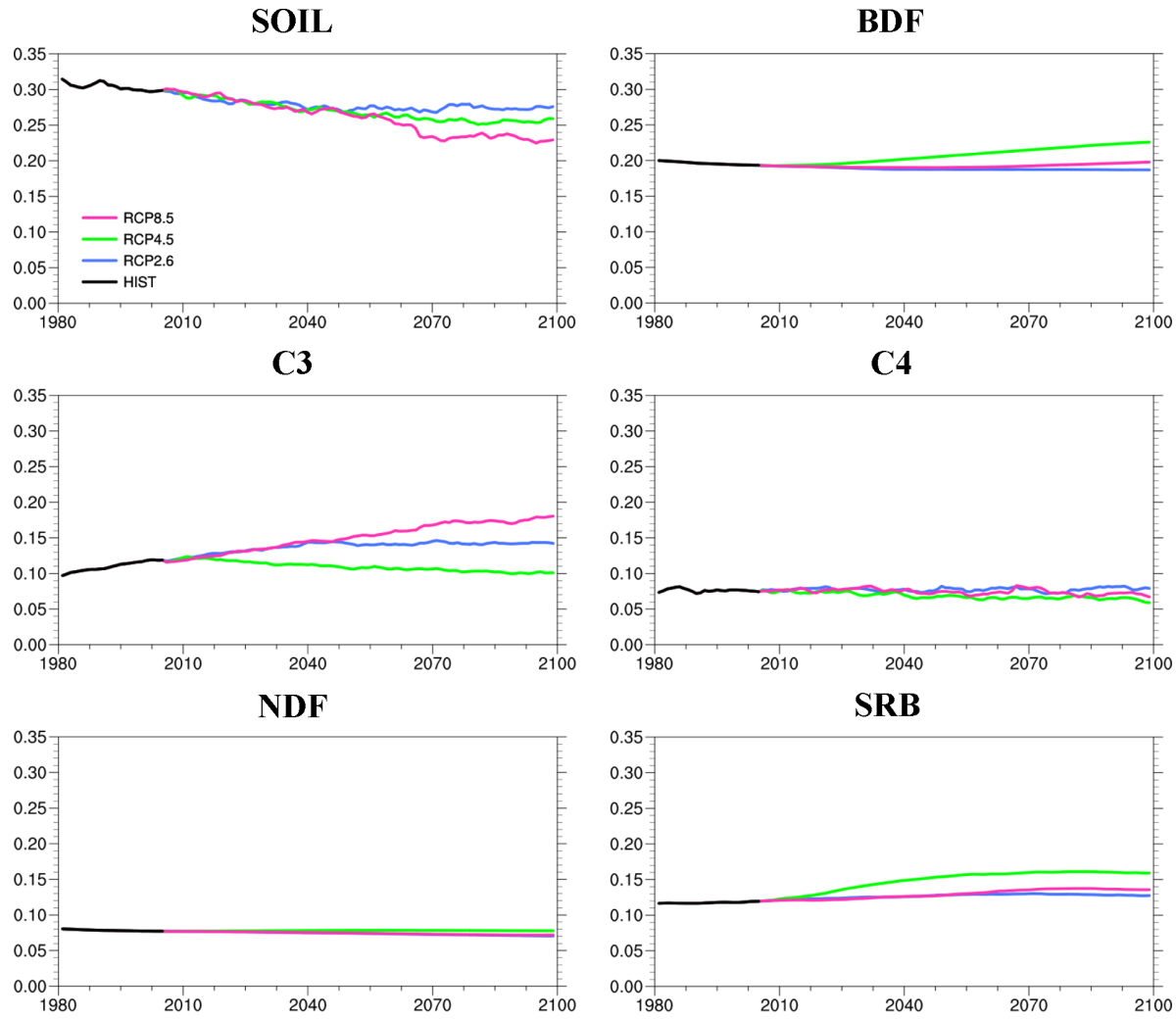

Fig. 4. Changes in the land surface fraction of broadleaf tree (BDF), needleleaf tree (NDF), C3 grass (C3), C4 grass (C4), shrub (SRB) and bare soil (SOIL) for three RCPs.

한국기상학회 대기 제24권 3호 (2014) 
Table 1. Changes (\%) of land cover fraction for broadleaf tree (BDF), needleleaf tree (NDF), C3 grass (C3), C4 grass (C4), shrub (SRB) and soil between the period of 2075 2099 from 1981 2005.

\begin{tabular}{rrrrrrr}
\hline \multirow{2}{*}{ RCPs } & \multicolumn{6}{c}{ Variables } \\
\cline { 2 - 7 } & BDF & NDF & C3 & \multicolumn{1}{c}{ C4 } & SRB & \multicolumn{1}{c}{ Soil } \\
\hline \hline RCP8.5 & $0 \%$ & $-7 \%$ & $58 \%$ & $-7 \%$ & $16 \%$ & $-23 \%$ \\
RCP4.5 & $13 \%$ & $0 \%$ & $-7 \%$ & $-15 \%$ & $36 \%$ & $-16 \%$ \\
RCP2.6 & $-4 \%$ & $9 \%$ & $29 \%$ & $2 \%$ & $9 \%$ & $-9 \%$ \\
\hline
\end{tabular}

는 $4.3 \%, \mathrm{RCP} 8.5$ 는 $5.7 \%$ 증가로 모든 시나리오에서 약간 많은 강수량을 보였다.

일반적으로 대기 중 이산화탄소 농도 증가에 따른 온난화와 강수량의 증가는 식생성장을 활발하게 하여 면적 증가와 식생 군 분포의 북상에 기여한다. 본 모 형 결과에서도 RCP 시나리오 3종 모두 북반구에서 모두 나지(bare soil) 면적이 감소하고 식생면적이 증 가함을 알 수 있다(Fig. 4). RCP 8.5 시나리오에서 나 지 면적이 $23 \%, \mathrm{RCP} 4.5$ 는 $16 \%, \mathrm{RCP} 2.6$ 는 $9 \%$ 의 감소가 모의되었다(Table 1). $\mathrm{RCP} 8.5$ 에서 $\mathrm{C} 3$ 식물, 관목 면적이 증가하였고 $\mathrm{RCP} 4.5$ 에서는 활엽수, 관목 면적이 증가하고 RCP 2.6에서는 활엽수를 제외한 모 든 식생타입에서 면적 증가가 모의되었으며, 이는 현 재 식물이 살기 어려운 북반구 고위도 지역에 기상 상승으로 인해 키가 낮은 초지(C3, C4 초지)와 관목 이 자라기 시작하고, 인구 증가에 따른 산림 벌채 및 농경지 증가와 관련이 있다(Fig. 5).

모든 시나리오에서 나지 면적은 감소하고 RCP 2.6/ 8.5 에서 $\mathrm{C} 3$ 초지의 면적은 증가하였는데, 이러한 나 지와 $\mathrm{C} 3$ 초지의 면적 변화는 다른 식생에 비하여 시 나리오 간 차이가 매우 컸다(Fig. 4). 이에 비해 활엽 수, 관목, 침엽수, $\mathrm{C} 4$ 초지의 면적변화는 상대적으로 시나리오 간 차이가 매우 작았다. $\mathrm{RCP}$ 시나리오별 $\mathrm{C} 3, \mathrm{C} 4$ 초지의 변화는 앞서 2장에서 설명한 것과 같 이 식생 성장에 있어 Fig. 2의 농작물, 목초지의 토지 사용변화의 영향이 반영되었기 때문으로 추정된다. $\mathrm{RCP} 2.6$ 시나리오와 $\mathrm{RCP} 8.5$ 시나리오는 $\mathrm{C} 3$ 초지의 면적은 증가하나 $\mathrm{RCP} 4.5$ 시나리오는 감소가 전망된 다. $\mathrm{RCP} 8.5$ 시나리오가 $\mathrm{C} 3$ 초지의 면적 증가율에서 $58 \%$ 로 큰 것은 Fig. 2의 식생계산과정에서 고려되는 토지사용변화에 대해 RCP 8.5는 산업발달과 인류증 가를 뒷받침하는 식량생산의 증가가 연관된 것이라 생각된다. 활엽수 면적은 $\mathrm{RCP} 4.5$ 시나리오에서는 증 가하는 반면 RCP 2.6/8.5 시나리오에서 감소하는데, 이 또한 이 시나리오상에서는 농경지 증가와 농경지 에서의 산림생태계로의 변화가 불가능하기 때문인 것 으로 추정된다. 관목에서는 3 개의 시나리오 중에 $\mathrm{RCP}$
4.5 시나리오에서 $36 \%$ 로 증가가 크며, 이는 대부분 남반구에서 발생했다. 이는 산림 벌채가 일어난 남아 메리카와 남아프리카 지역이 RCP 2.6/8.5 시나리오에 서는 증가한 인구를 지탱하기 위해 농경지로 사용되 는 반면, RCP 4.5 시나리오에서는 자연 상태에서 21 세기 동안 관목으로의 천이가 일어났기 때문이다(Fig. 5).

21세기 말 나지 면적의 감소를 위도대별로 살펴보 면 북반구와 남반구 모든 위도 대에서 나타나고 있다 (Fig. 5). 북위 60도 이상 지역에서 나지 면적이 감소 하는 것은 활엽수가 증가하고 관목의 면적 증가가 주 요한 원인으로, 이는 적분 기간 동안 자연 경쟁에 의 해 나지가 초지 $(\mathrm{C} 3, \mathrm{C} 4$ 초지)로 천이한 뒤 급격하게 관목으로 바뀐 것과 연관된다. 침엽수는 상대적으로 $60^{\circ} \mathrm{N}$ 를 기준으로 남쪽에서는 감소, 북쪽에서는 증가 를 모의하였는데, 인구 증가에 따라 농경지 개척이 고 위도에서 일어나면서 고위도에 상대적으로 많이 존재 하는 침엽수 면적이 줄어들어 발생한 것으로 생각된 다. 관목이 감소하는 지역을 살펴보면 침엽수가 증가 하는 모습을 보이고 있으며 침엽수와 활엽수 또한 비 슷한 현상이 일어남을 알 수 있다. 여기서 온난화로 인해 일부 식생의 북방한계선이 북상함을 알 수 있고, 북반구 고위도에서는 육상 식생 종류가 변화함을 알 수 있다. 한 예로 Fig. 5에서 북위 60도 이상 고위도 지역에서 관목면적이 증가하는 것을 들 수 있으며 이 는 기온 상승의 기후조건 변화가 식생성장에 영향을 준 것으로 분석된다.

반면, 적도를 포함한 열대지역에서는 활엽수가 감 소하고 $\mathrm{C} 3$ 초지의 면적 증가가 모의되었는데 이는 산 림 벌채와 농경지 확대 및 초지로의 식생 천이 때문 인 것으로 추정된다(Table 1, Fig. 5). RCP 2.6의 각 식생 유형의 위도대별 면적변화는 RCP 8.5 와 절대값 의 차이는 있으나 대체적인 변화분포는 유사하다. 상 대적으로 RCP 4.5 시나리오는 Figs. 2, 4에서 보이는 것과 같이 $\mathrm{RCP} 2.6$ 및 8.5 에 비하여 $\mathrm{C} 3$ 초지 면적이 감소하고 이는 위도대별로 증감 경향이 다르다. 특히 모든 식생 군의 면적변화가 적도를 포함한 남반구 위 도 대에서 다르게 나타났다. 이러한 결과는 Liddicoat et al. (2013)가 대기-해양 및 탄소, 생태역학, 대기화 학을 접합하여 실험한 HadGEM2-ES 모형에서의 농 경지 대량확장으로 인한 식생면적변화와 비슷한 결과다.

\subsection{NEE 변화 전망}

실제 육상 생태계가 대기 중 이산화탄소의 발원인 지 아니면 흡원인지는 식물의 광합성에 의한 총일차 생산량(Gross Primary Productivity, GPP)과 생태계 호 흡의 차이인 순 이산화탄소 교환량(Net Ecosystem Exchange, NEE)으로 결정된다. 생태계 호흡량(Terrestrial Ecosystem Respiration, TER)은 식물에 의한 호흡(Plant 
(a) RCP8.5
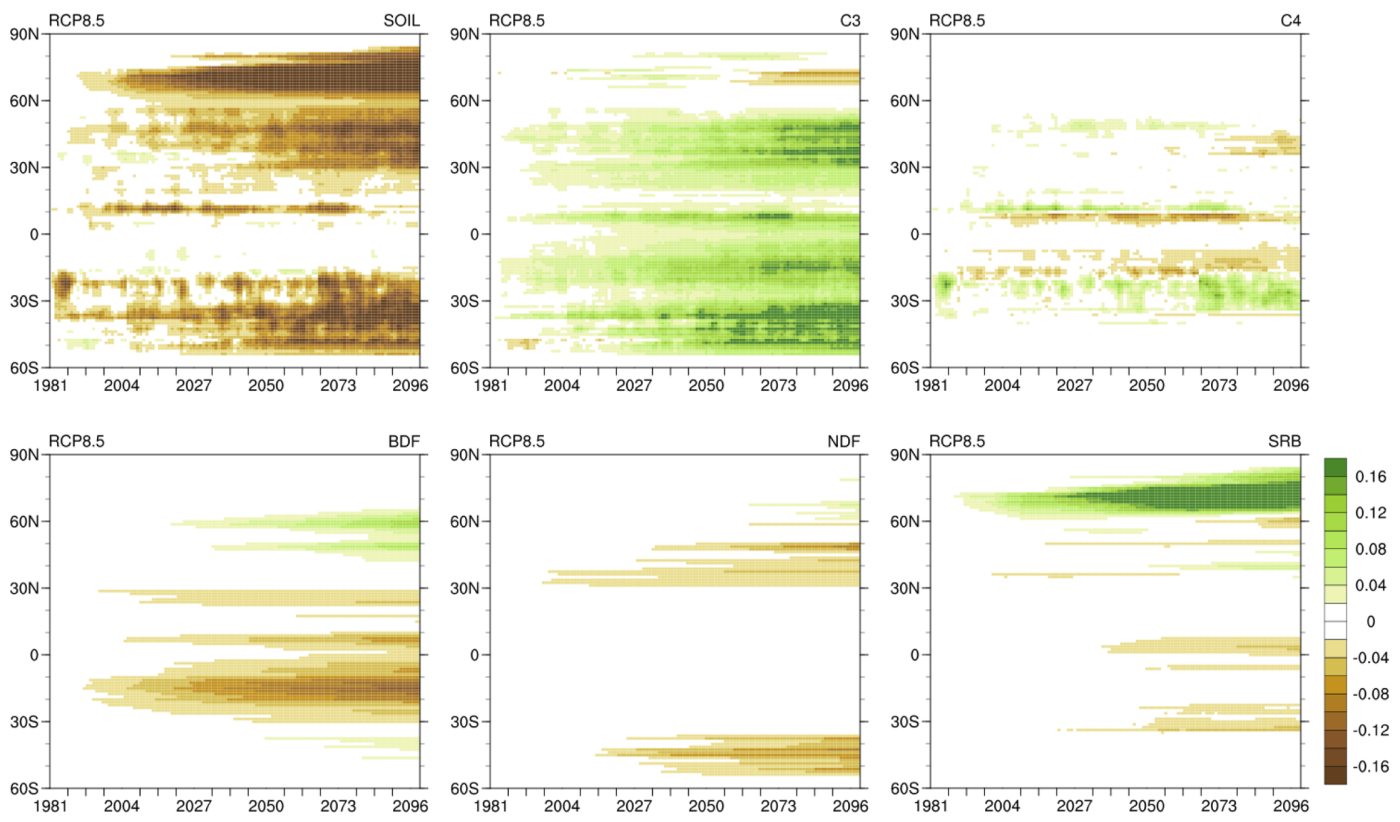

(b) RCP4.5
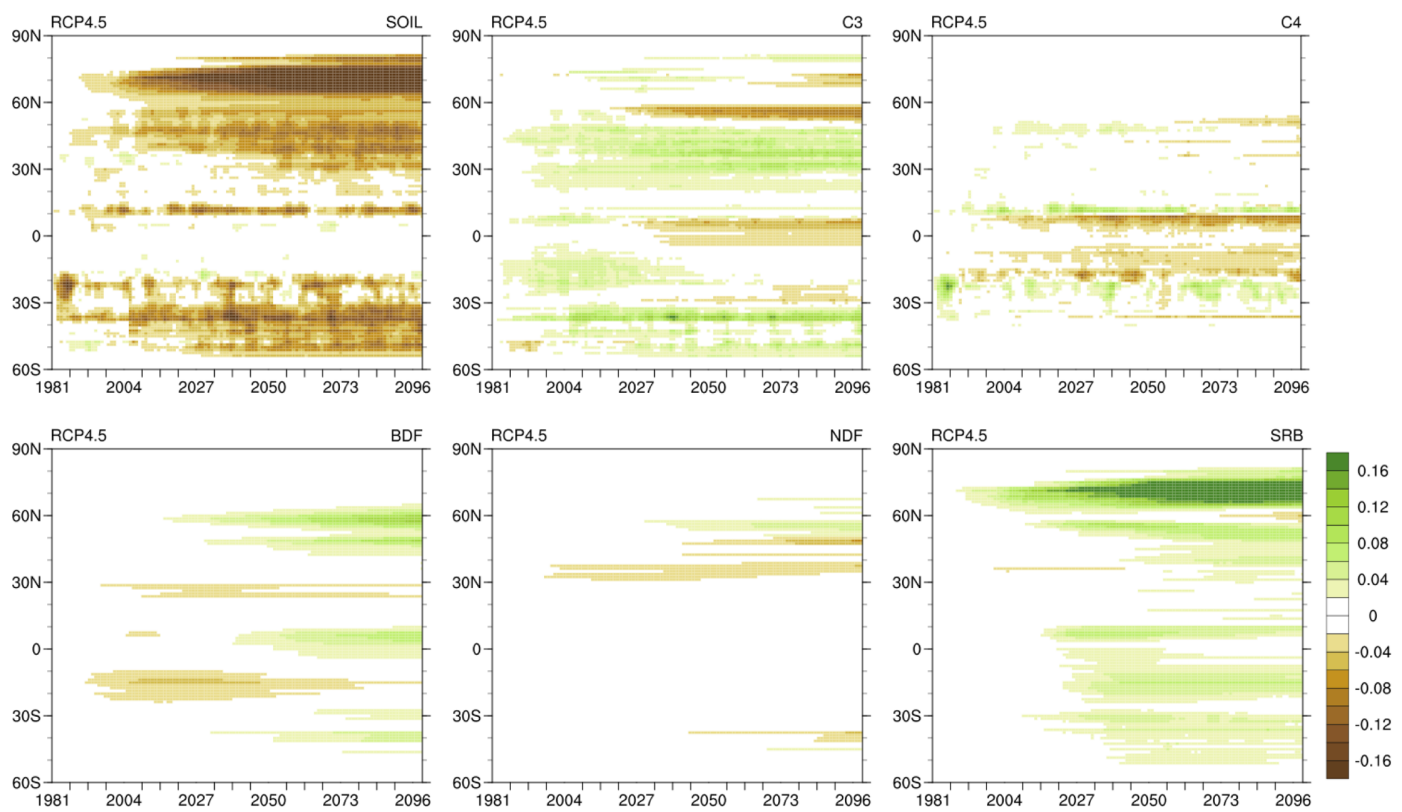

Fig. 5. Latitude-time plots of change in fractional coverage of Soil, C3, C4, BDF, NDF and SRB relative to the 1981 year mean for (a) RCP8.5, (b) RCP4.5.

Respiration, Rp)과 토양에 의한 호흡량(Soil Respiration, $\mathrm{Rs})$ 으로 구성된다. 한편 순 이산화탄소 교환량(NEE) 은 식물의 자가 호흡(Rp)과 순일차생산량 $(\mathrm{NPP}, \mathrm{Net}$ Primary Production)의 차이로 계산할 수 있다. 순일차
생산량(NPP)은 식물의 광합성에 의해 저장된 총일차 생산량에서 식물의 성장과 유지에 사용되는 호흡량을 제한 값을 말하는데 식 (1)과 같이 광합성량과 식물 의 자가 호흡량의 차이로 계산할 수 있다(Fig. 6).

한국기상학회 대기 제24권 3호 (2014) 


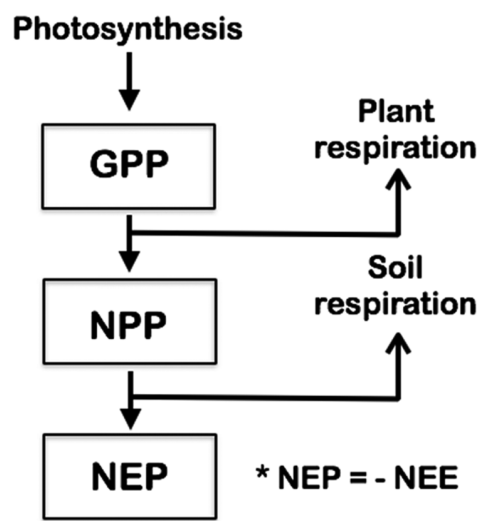

Fig. 6. Representation of terrestrial carbon budget components of GPP, NPP, NEP, NEE in this study.

$$
\mathrm{NPP}=\mathrm{GPP}-\mathrm{Rp}
$$

순생태계생산량(Net Ecosystem Production, NEP)은 식 (2)와 같이 총일차생산량 $(\mathrm{GPP})$ 과 생태계 호흡량 (TER)의 차로, 이것은 식 (3)처럼 대기와 생태계 간의 이산화탄소 교환량(NEE)을 나타내는 용어로 흔히 사 용되고 있다(Fig. 6). 본 연구의 1981 2011년간 적분
결과를 볼 때 $\mathrm{RCP}$ 시나리오 3종 평균값은 $\mathrm{NEE}, \mathrm{GPP}$,

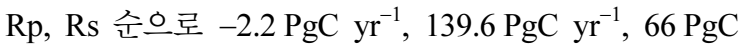
$\mathrm{yr}^{-1}, 71.4 \mathrm{PgC} \mathrm{yr}^{-1}$ 로 각각 모의되었다. 특히 $\mathrm{NEE}$ 는 Quéré et al. (2013) 결과와 매우 흡사한 결과이다. 이 연구에서 사용된 생태모형의 GPP, RE (Ecosystem Respiration)가 온도 및 모수화과정변화에 따른 민감도 에 대해서는 장지현 외(2010)에서 다루어졌다.

$$
\begin{aligned}
& \mathrm{NEP}=\mathrm{NPP}-\mathrm{Rs}, \\
& \mathrm{NEE}=-\mathrm{NEP} .
\end{aligned}
$$

육상생태계가 $\mathrm{CO}_{2}$ 흡수원으로서 얼마만큼 역할을 하는지 NEE의 추세를 살펴보았다(Fig. 7). NEE의 음 의 영역은 대기 중 $\mathrm{CO}_{2}$ 흡수이고, 양의 영역은 대기 로 $\mathrm{CO}_{2}$ 배출을 의미한다. Figure 1 의 $\mathrm{RCP}$ 별 대기 중 이산화탄소 농도 증가 경향에 따라 육상생태계에서 $\mathrm{CO}_{2}$ 흡수량 변화가 영향 받음을 알 수 있다. 대기 중 이산화탄소 증가율이 가장 큰 $\mathrm{RCP} 8.5$ 에서 21세기 말 육상생태계의 $\mathrm{CO}_{2}$ 흡수량 증가가 가장 크고, $\mathrm{RCP} 4.5$, $\mathrm{RCP} 2.6$ 의 순서로 농도증가율에 비례해서 흡수율이 변화한다. RCP 8.5 시나리오는 21세기 말에 대기 중 이산화탄소 농도는 계속 증가하고, 북반구 고위도 지 역의 기온과 강수 증가에 의해 늘어난 총일차생산량

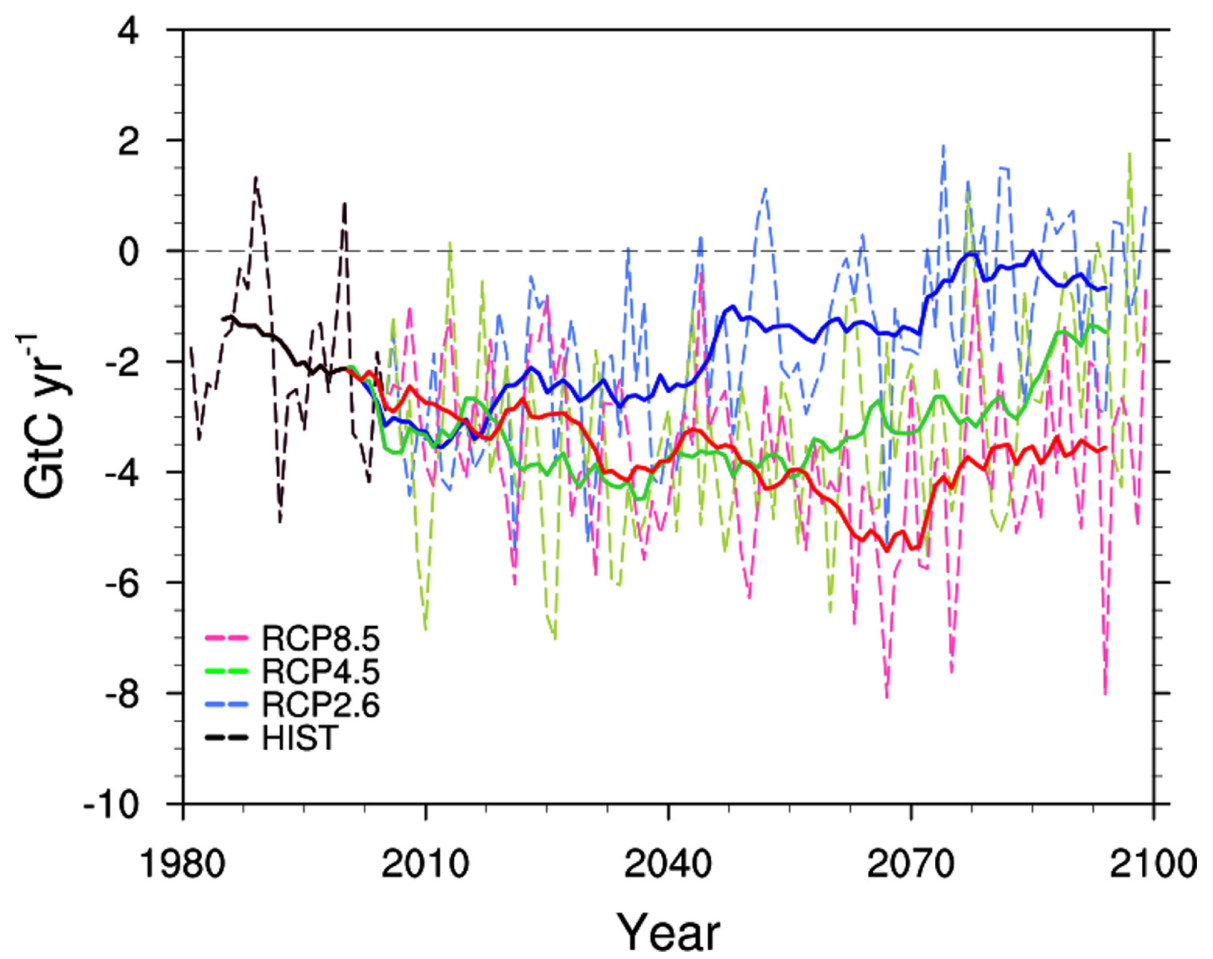

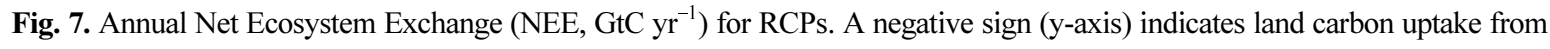
the atmosphere. Thick solid line is 10 -year moving average. 


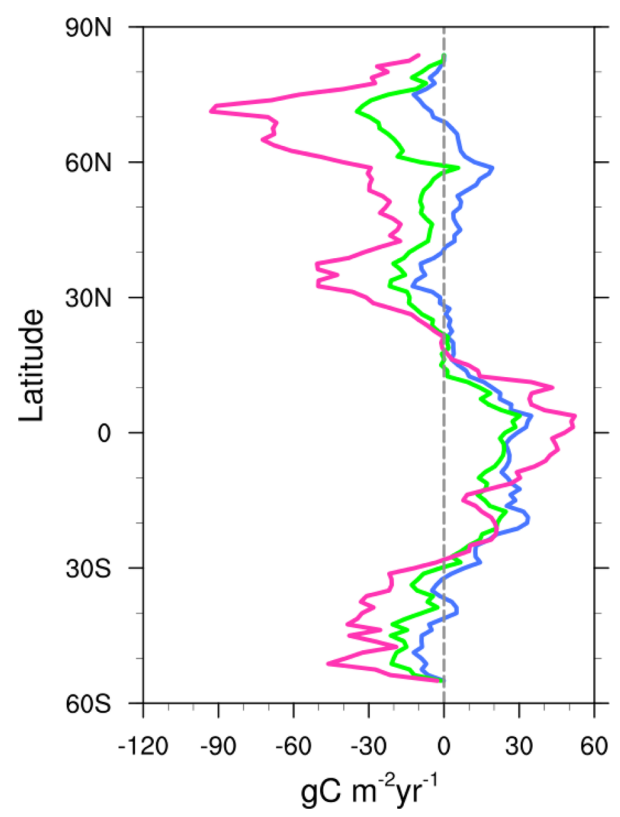

Fig. 8. Changes in NEE $\left(\mathrm{gC} \mathrm{m}^{-2} \mathrm{yr}^{-1}\right)$ at the end of $21 \mathrm{st}$ century (2075 2099) for RCPs relative to the period of 1981 2005. A negative sign (x-axis) means land carbon uptake from the atmosphere, positive sign (x-axis) means land carbon emission to the atmosphere. Red, green, blue lines mean RCP8.5, 4.5 and 2.6 repectively.

으로 인하여 대기 중 이산화탄소 흡수량이 현재보다 크게 증가하였다(Figs. 7, 8). 고위도 지역의 탄소흡수 에 대해서는 Shao et al. (2013)와 유사한 결과를 보 였으며 이와 관련해서는 시베리아 50 도 이북지역의 아한대림(boreal forest)의 역할을 언급되었다. 하지만 Fig. 7의 RCP 8.5에서는 기온이 21세기 후반에 급격 하게 상승하였고, 이러한 기온의 급상승은 생태계 호 흡량의 급격한 증가를 가져와 2070년 이후부터 NEP 가 감소하는 경향을 보였다. 이와 함께, 위에서 언급 한 것처럼 $\mathrm{RCP} 8.5$ 에서는 고위도에서 크게 증가한 기 온의 영향으로 이곳에서 관목(shrub)이 자라게 되고, 중위도 지역에서 늘어난 농경지가 현재보다 증가한 $\mathrm{NEP}$ 에 상당 부분 기여했음을 추정할 수 있다(Figs. 4 5 and 10). 반면 RCP 2.6 시나리오에서는 RCP 8.5 시나리오에 비교했을 때, 현재 지표 피복과 크게 달 라지지 않은 상태에서 기온 상승에 의한 토양 호흡량 의 증가로 인하여 21 세기 초반부터 육상 생태계의 탄 소 흡수 능력이 감소하는 것으로 보인다(Figs. 10 11). 시나리오에 따른 위도별 NEE의 변화를 보면 이러한 차이가 확인된다(Fig. 8). 한편, 3 개의 서로 다른 시나 리오가 모두 열대 우림 지역의 호흡량 증가와 맞물려 적도 지방에서는 대부분 육상생태계의 탄소 흡수 능

\section{(a) Temperature}

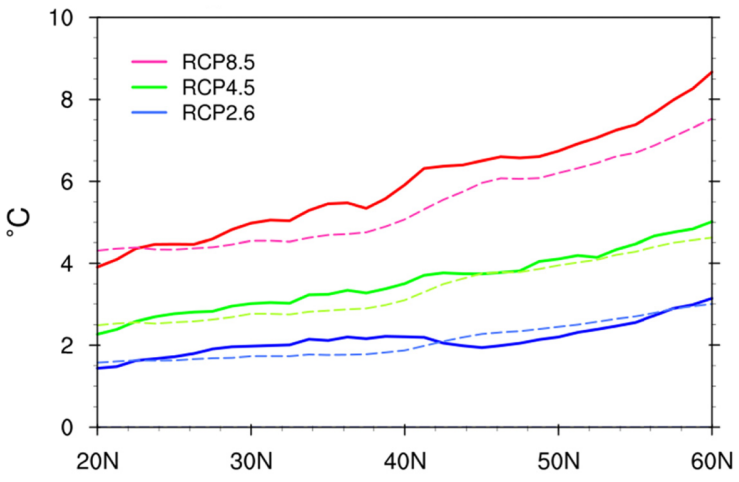

(b) Precipitation

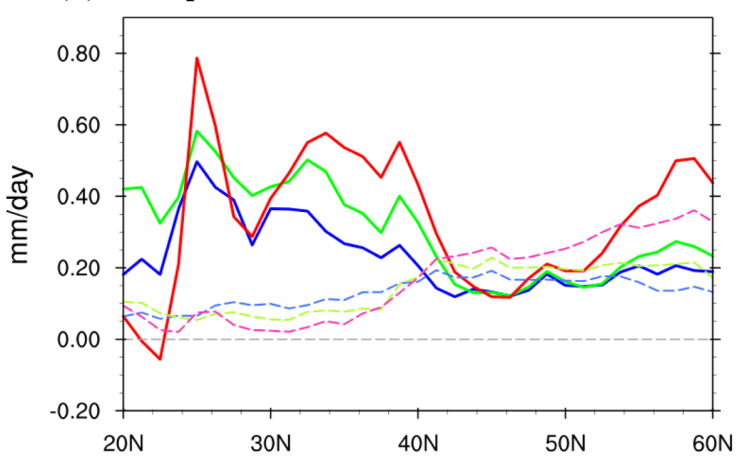

(c) NEE

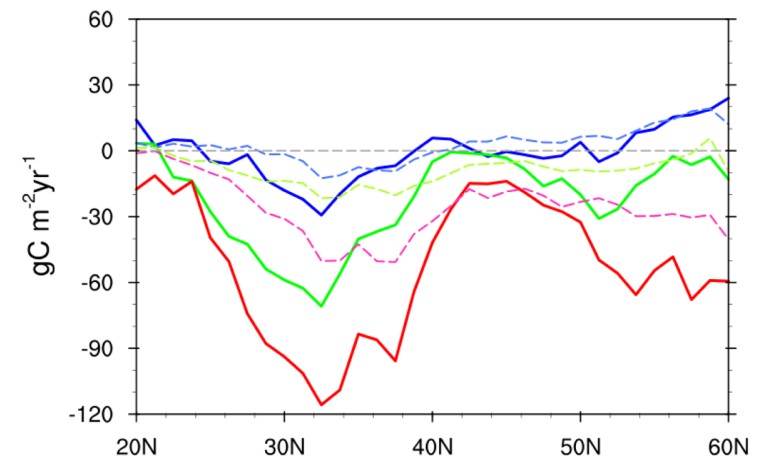

Fig. 9. Future changes in (a) temperature $\left({ }^{\circ} \mathrm{C}\right)$, (b) precipitation $\left(\mathrm{mm} \mathrm{day}^{-1}\right)$, (c) NEE $\left(\mathrm{gC} \mathrm{m}^{-2} \mathrm{yr}^{-1}\right)$ for the zonal mean from $20^{\circ} \mathrm{N}$ to $60^{\circ} \mathrm{N}$ and East Asia $\left(90^{\circ} \mathrm{E} \sim 140^{\circ} \mathrm{E}\right.$, $20^{\circ} \mathrm{N} \sim 60^{\circ} \mathrm{N}$ ) from RCPs over the period of $2075 \sim 2099$ minus 1981 2005. Dashed line is zonal $\left(20^{\circ} \mathrm{N} \sim 60^{\circ} \mathrm{N}\right)$ mean and thick solid line is East Asia $\left(90^{\circ} \mathrm{E} \sim 140^{\circ} \mathrm{E}, 20^{\circ} \mathrm{N} \sim 60^{\circ} \mathrm{N}\right)$ mean. (c) A negative sign (y-axis) means land carbon uptake from the atmosphere.

력이 미래에 크게 감소한다는 것을 알 수 있다(Fig. 8). RCP 4.5 시나리오에서 나타난 $\mathrm{NEE}$ 의 미래 변화 는 북반구에서는 $\mathrm{RCP} 8.5$ 와 유사하게 $\mathrm{CO}_{2}$ 흡수량이 
GPP

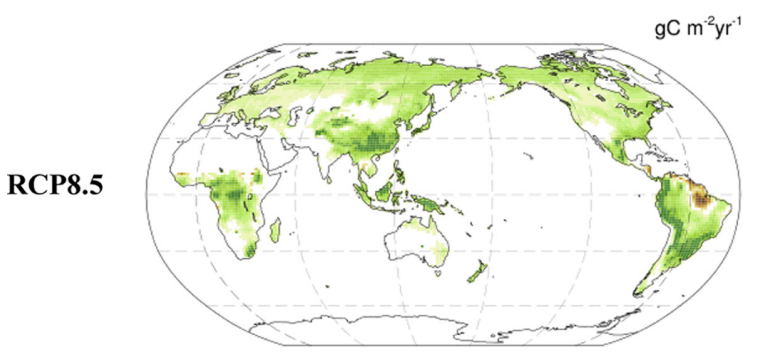

$\mathrm{gC} \mathrm{m}^{-2} \mathrm{yr}^{-1}$
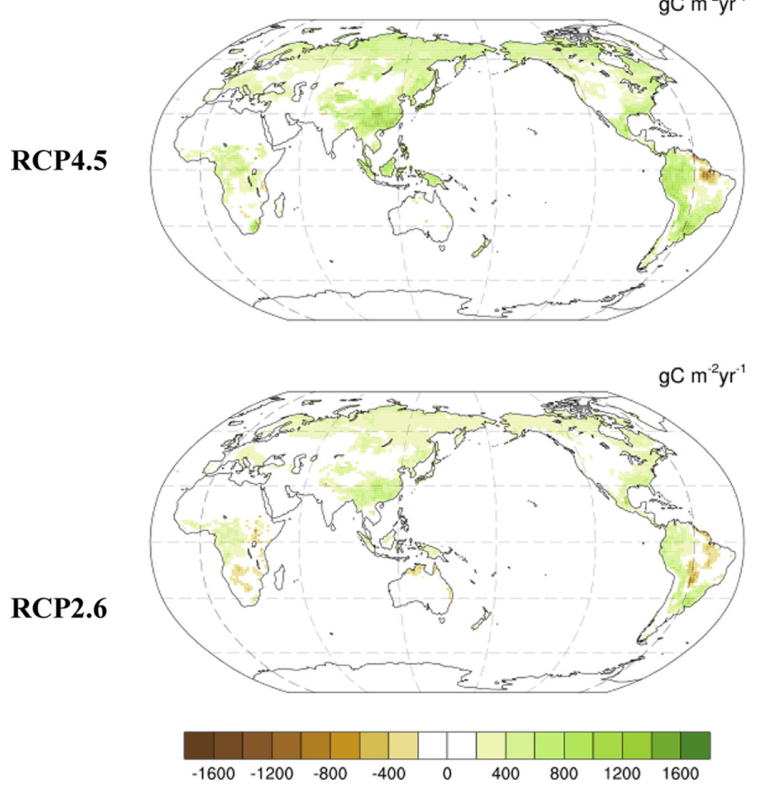

NPP
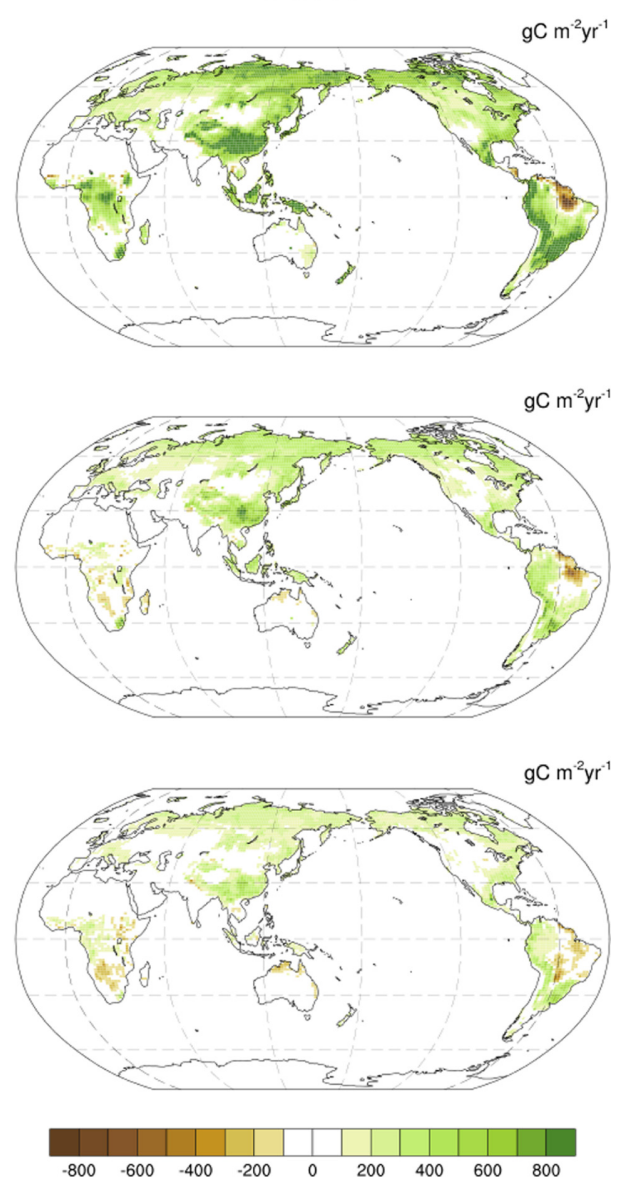

Fig. 10. Changes in GPP (Gross Primary Production, $\mathrm{gC} \mathrm{m}^{-2} \mathrm{yr}^{-1}$ ) and NPP (Net Primary Production, $\mathrm{gC} \mathrm{m}^{-2} \mathrm{yr}^{-1}$ ) for RCPs between the periods (2075 to 2099) - (1981 to 2005).

현재보다 증가하고 그 흡수량은 상대적으로 작게 모 의되었다.

한편, 우리나라가 속해있는 동아시아 지역 $\left(90^{\circ} \mathrm{E} \sim\right.$ $\left.140^{\circ} \mathrm{E}, 20^{\circ} \mathrm{N} \sim 60^{\circ} \mathrm{N}\right)$ 의 21 세기 말 $(2075 \sim 2099)$ 이산화탄 소 흡수량 평균값은 RCP 8.5, 4.5, 2.6 순으로 -2.09 $\mathrm{PgC} \mathrm{\textrm {yr } ^ { - 1 }},-1.12 \mathrm{PgC} \mathrm{yr}^{-1},-0.47 \mathrm{PgC} \mathrm{yr}^{-1}$ 로 같은 위 도대의 전지구동서평균 $-1.12 \mathrm{PgC}^{-1},-0.55 \mathrm{PgC}$ $\mathrm{yr}^{-1},-0.17 \mathrm{PgC} \mathrm{yr}^{-1}$ 보다 탄소 흡수량이 큰 것으로 모 의되었다(Figs. 8 and $9 \mathrm{c}$ ). 같은 위도대의 전지구 평 균에 비하여 동아시아 지역의 기온 및 강수량 증가 는 상대적으로 매우 컸고 기온, 강수량의 증가가 식 생 성장에 좋은 조건을 제공한 것으로 판단된다(Figs. 9a, b).

\subsection{GPP, NPP 변화 전망}

Figures 4,5 에서 모의된 나지 면적의 축소와 식생
의 면적 증가는 총일차생산량 $(\mathrm{GPP})$ 과 순일차생산량 (NPP)의 증가로 나타난다(Fig. 10). 미래 RCP 시나리 오에 따라 식생광합성량의 증가는 Shao et al. (2013) 에서도 동일한 결과를 보였다. GPP 증가율은 RCP 8.5 시나리오에서 약 $60 \%$ 로 가장 크고 $\mathrm{RCP} 4.5, \mathrm{RCP} 2.6$ 의 순으로 작았다(Table 2). RCP 시나리오에 따른 NPP 증가율 역시 GPP 결과와 동일한 결과를 보이고 생산 량 차이만을 보이는데, 이는 NPP는 식 (1)과 같이 계 산되기 때문이다. 이 증가는 열대우림지역, 그리고 남 아시아, 인도네시아 지역에서 크다(Fig. 10). 전 지구 대부분의 지역에서 $\mathrm{GPP}, \mathrm{NPP}$ 가 증가하지만 $\mathrm{RCP}$ 시 나리오 3종 모두 아마존 지역에서 눈에 띄게 감소하 는 것으로 모의된다. 이는 아마존 지역의 21세기 말 강수량 변화와 관련이 있는 것으로 판단되며 기존 연 구들(Betts et al., 2004; Notaro et al., 2007; Good et $a l ., 2011)$ 에 따르면 기후변화에 따른 가뭄으로 인해 


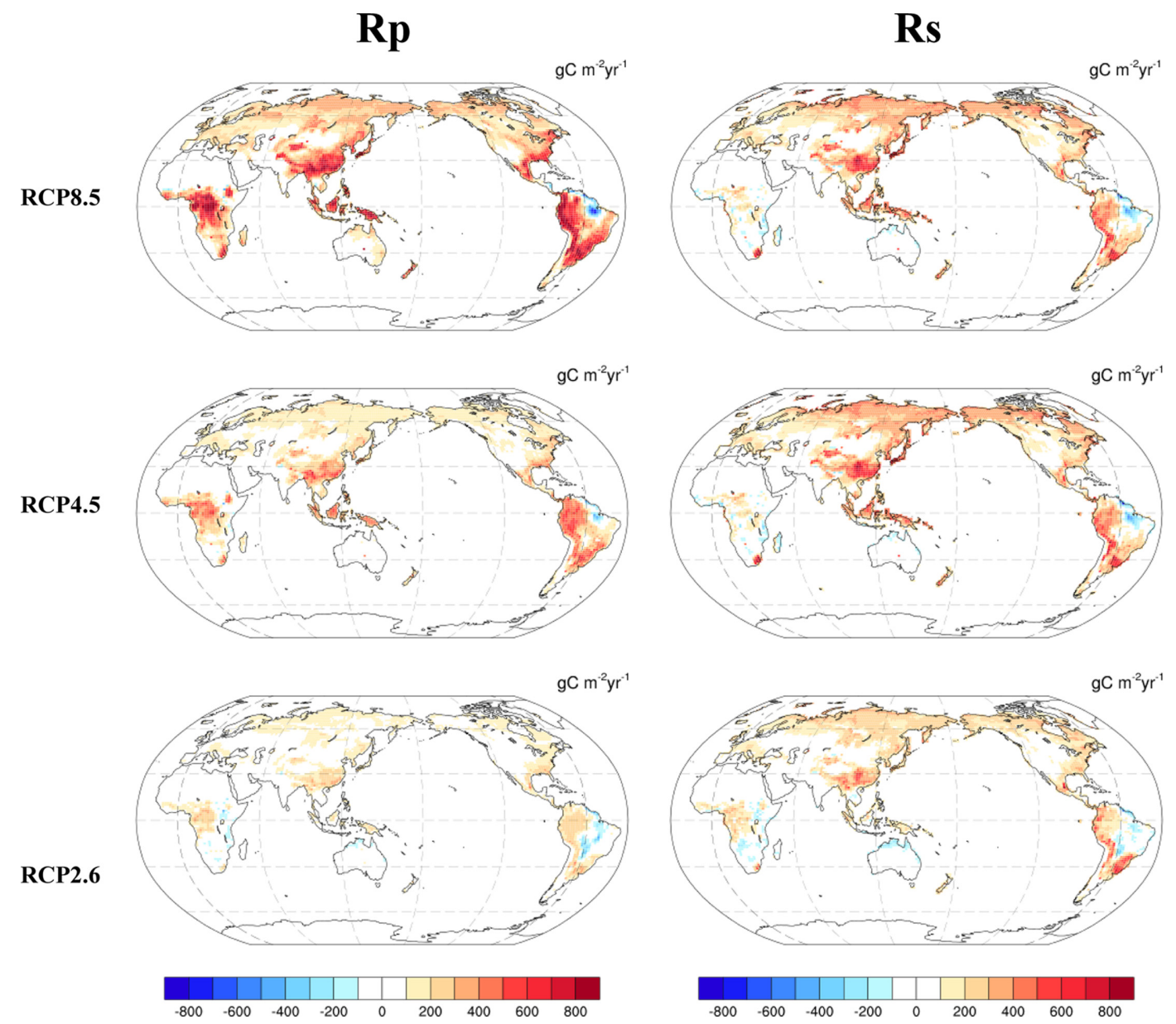

Fig. 11. Changes in Rp (Plant Respiration, $\mathrm{gC} \mathrm{m}^{-2} \mathrm{yr}^{-1}$ ) and Rs (Soil Respiration, $\mathrm{gC} \mathrm{m}^{-2} \mathrm{yr}^{-1}$ ) for RCPs between the periods (2075 to 2099) - (1981 to 2005).

산림면적의 감소 가능성이 언급되었다.

\section{4 호흡량 변화 전망}

Figure 11는 육상생태계의 생산량(GPP, NPP)와 밀 접한 관계를 맺고 있는 식물 및 토양에 의한 호흡량 을 보여준다. 앞서 Fig. 10에서 나타난 NPP 증가가 뚜렷한 지역에서 $\mathrm{Rp}$ 와 $\mathrm{Rs}$ 역시 크게 나타난다. $\mathrm{Rp}$, Rs 모두 RCP 8.5 시나리오에서 약 $51 \%, 58 \%$ 의 가 장 큰 증가량을 보이며 $\mathrm{RCP} 4.5 / 2.6$ 에서도 증가한다 (Table 2). 20세기 말 대비 21세기 말에 기온증가에 따라 생산량(GPP, NPP), 호흡량이 증가한다는 선행연 구(e.g., Shao et al., 2013)와 비슷한 결과를 보인다. 식물 호흡과 토양 호흡의 전지구 변화는 비슷한 공 간 형태를 보여준다. 하지만 GPP 증가 형태와 비슷 한 식물 호흡과는 달리, 토양 호흡은 적도 부근의 아 프리카에서 증가를 보이지 않았고, 북반구 고위도에
Table 2. Changes (\%) of GPP (Gross Primary :qProduction), NPP (Net Primary Production), Rp (Plant Respiration), Rs (Soil Respiration) between the period of 2075 2099 from 1981 2005.

\begin{tabular}{ccccc}
\hline \multirow{2}{*}{ RCPs } & \multicolumn{4}{c}{ Variables } \\
\cline { 2 - 5 } & GPP & NPP & Rp & Rs \\
\hline \hline RCP8.5 & $60 \%$ & $59 \%$ & $51 \%$ & $58 \%$ \\
RCP4.5 & $27 \%$ & $26 \%$ & $29 \%$ & $27 \%$ \\
RCP2.6 & $14 \%$ & $15 \%$ & $13 \%$ & $18 \%$ \\
\hline
\end{tabular}

서 식물 호흡에 비해 보다 큰 증가를 보여준다. 이는 아프리카 적도 지역이 미래에 상대적으로 기온상승 효과가 적은데 비해 북반구 고위도의 온도 상승이 다 른 위도대에 비해서 컸기 때문이다. 그리고 아마존 지역의 호흡량은 기온 상승에도 불구하고 큰 변화가 
(a) LAI

\section{RCP 8.5}

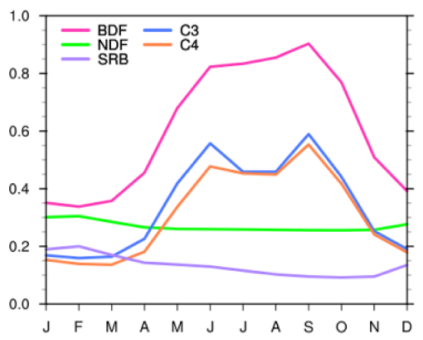

RCP4.5

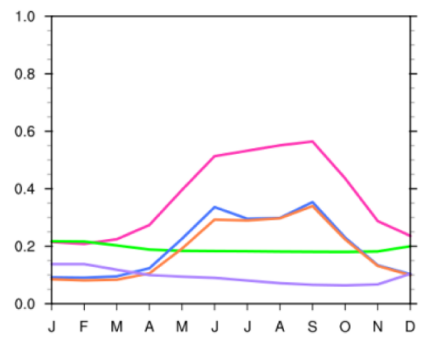

RCP2.6

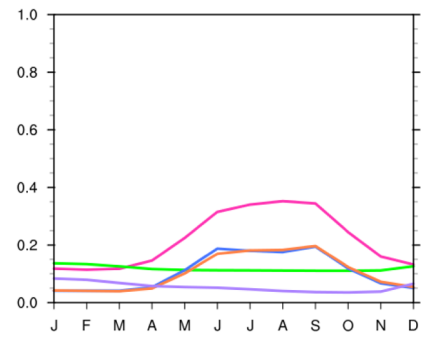

(b) NEE

HIST : BDF

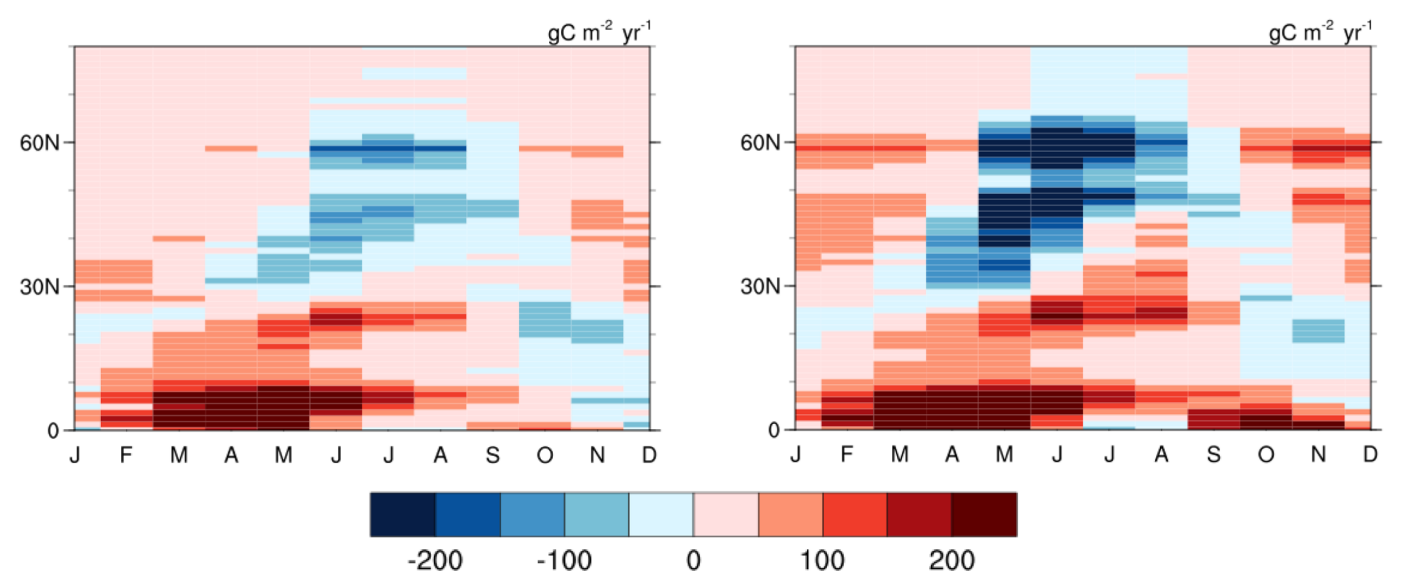

Fig. 12. (a) Global monthly mean LAI (index) change of BDF, NDF, C3, C4 and SRB for RCPs between the periods (2075 to 2099) - (1981 to 2005). (b) Latitude-time plot of NEE ( $\left.\mathrm{gC} \mathrm{m}^{-2} \mathrm{yr}^{-1}\right)$ mean of BDF for historical and RCP8.5 simulations. A negative sign (blue) means land carbon uptake from the atmosphere.

없었는데, 이는 이 지역의 기온 상승과 강수 감소로 인한 토양 수분 감소가 서로 상쇄되어 나타난 것으 로 추정된다.

\section{$3.5 \mathrm{LAI}$ 변화 전망}

대기 중 $\mathrm{CO}_{2}$ 농도와 온도증가, 강수증가에 따른 육 상생태계의 잎면적지수(LAI, Leaf Area Index)와 성장 시기(Growing season)의 길이변화를 살펴보았다. 21세 기 말 $\mathrm{LAI}$ 는 20 세기 말 대비 모든 식생 군에서 증가 하였다(Fig. 12a). RCP 8.5의 LAI 증가율이 가장 크고 $\mathrm{RCP} 4.5, \mathrm{RCP} 2.6$ 의 순서로 증가율이 컸으며 진폭이 다를 뿐 식생종류에 따른 월별 증가율의 변화형태는 동일하다. 활엽수와 $\mathrm{C} 3$ 초지의 $\mathrm{LAI}$ 는 식생 성장시기 에 특히 증가가 크다. 한편 침엽수와 관목의 $\mathrm{LAI}$ 는 연 중 비슷한 증가율을 보이는데 이는 엽면적지수 모수 과정에 대한 모델 특성으로 판단되며 추가조사가 필 요하다. Figure 12에서 나타난 월별 $\mathrm{LAI}$ 의 급격한 증
가율은 모든 시나리오에서 유사한 경향을 나타내고 있 는데 이와 더불어 식생의 성장 시기(Growing season) 도 21세기 후반에 1 2달 정도 길어졌다(Fig. 12b).

식생의 성장시기의 길이 증가는 식생별 $\mathrm{NEE}$ 에서 잘 나타나는데 20세기 말 대비 21세기 말 모든 $\mathrm{RCP}$ 에서 식생의 $\mathrm{CO}_{2}$ 흡수의 시작시기가 앞당겨지고 흡 수하는 강도도 커지는 것이 전망되었다(Fig. 12b). 활 엽수의 경우 20 세기 말에 $60^{\circ} \mathrm{N}$ 부근에서 $\mathrm{CO}_{2}$ 흡수하 는 시기가 6월 9월이던 것이 RCP 8.5 에서 21세기 말 5월 9월로 한 달 정도 앞당겨지면서 성장시기가 길어 지고 이산화탄소 흡수량도 많아지며 북위 $60^{\circ} \mathrm{N}$ 이상 고위도 흡수량도 증가하였다. 이런 경향은 침엽수, 초 지 $(\mathrm{C} 3, \mathrm{C} 4$ 초지 $)$, 관목의 경우에도 비슷하게 나타났다.

\section{4. 요 약}

HadGEM2-CC 모델에서의 $\mathrm{CO}_{2}$ 농도증가에 대한 
$\mathrm{RCP}$ 시나리오의 결과는 21 세기 말 전 지구 연평균 기온과 강수 증가가 전망되고 이에 따라 식물의 생산 량 및 호흡량 증가가 전망된다. 20세기 말 일차생산 량(GPP와 NPP), 호흡량, LAI가 21세기 말 기온 증가 에 따라 증가하는 점은 기존의 Shao et al. (2013)와 유사하였다. 특히 이전 연구와 유사하게 21세기 말 일 차생산량과 호흡량은 고위도보다 열대 저위도 지역에 서 증가량이 더 컸다. 기온이 상승하고 강수량이 증 가하면서 식생이 자라지 않던 나지 면적이 감소하였 고, 이에 따른 식생 면적 증가는 식생의 생산량 $(\mathrm{GPP}$, $\mathrm{NPP})$ 증가로 나타났다. 특히, 본 연구에서는 C3 초지, 활엽수의 면적 증가가 뚜렷하였다. 이는 Beck and Goetz (2011)에서 언급한 대로 온난화에 따른 식생 면 적 증가가 식생 생산성과 연관되어 $\mathrm{CO}_{2}$ 흡수작용을 강화하는 데 기여할 수 있음을 의미한다.

Shao et al. (2013)에 따르면 21세기 말 누적 NEE 는 증가가 전망되고 이는 특히 열대와 고위도 지역이 주요 흡수원으로 작용하였기 때문으로 그 원인을 설 명하였다. 본 연구에서 사용된 HadGEM2-CC에서는 전 지구 평균적으로 $\mathrm{NEE}$ 흡수가 증가하는 경향은 동 일하게 전망하며, 이는 열대보다는 북반구 고위도지 역인 유라시아와 북미 대륙에서 증가한 흡수가 그 원 인으로 분석되었다(Fig. 8).

앞서 Mynenl et al. (1997)에 따르면 기온상승에 따 라 식생의 광합성활동, 생장시기 길이와 시작시기의 당겨짐을 보고하였다. 본 연구 실험에서도 이와 유사 하게 미래에 기온 상승에 따라 식생 성장 기간이 길 어지고 LAI도 증가하며 식생 지대가 점차 고위도로 북상할 것을 전망하였다(Figs. $5,12 \mathrm{~b}$ ). 이에 따라 육 상 생태계의 $\mathrm{CO}_{2}$ 흡수량은 20세기 말보다 21세기 말 에 증가하였고 우리나라가 속해있는 동아시아지역 $\left(90^{\circ} \mathrm{E} \sim 140^{\circ} \mathrm{E}, 20^{\circ} \mathrm{N} \sim 60^{\circ} \mathrm{N}\right)$ 은 기온, 강수뿐 아니라 $\mathrm{CO}_{2}$ 흡수량도 같은 위도대의 전 지구 동서평균보다 크게 모의되었다. RCPs에 따른 흡수율은 21세기 중반까지 는 대기 중 이산화탄소 농도 변화율과 유사한 경향을 보이는데 RCP 8.5 에서는 21세기 후반에 흡수 증가율 이 감소하며 이는 Liddicoat et al. (2013) 에서 보인 것과 유사하다. 하지만 대기 중 $\mathrm{CO}_{2}$ 의 증가와 식생 분포 지역의 확대에도 불구하고 21 세기 말 육상생태 계의 순생태계흡수량은 크게 증가하지 않음을 확인할 수 있었다. 이는 기온 상승이 크게 일어난 21세기 후 반부터 토양 호흡의 급격한 증가로 인하여 육상생태 계의 이산화탄소 흡수 능력은 감소한 것에 기인하였다.

향후 본 연구결과의 유의성을 확보하기 위해 다양 한 모델의 자료를 추가할 필요가 있다. Shao et al. (2013)에 따르면 미래 탄소 흡수 전망에 있어 전 지 구 및 위도별 모의 결과가 모델마다 매우 다양한데 이는 지면생태모형 간의 식생역학, 물리과정의 차이
로 해석된다. 미래 육상생태계의 이산화탄소 흡수 능 력의 변화와 기후변화를 보다 정확하게 예측하기 위 해서는 다른 모델의 자료를 이용한 불확실성을 정량 화 하는 것이 필요하며 이는 전 지구 및 지역별 탄소 순환 이해를 높이는 데 기여할 것이다.

\section{감사의 글}

이 연구는 'NIMR-2012-B-2(기후변화 예측기술 지 원 및 활용연구)'와 기상청 기상기술개발사업(CATER 2012-3055)의 지원으로 수행되었습니다. 이에 감사드 립니다.

\section{REFERENCES}

Baek, H.-J., and Coauthors, 2013: Climate change in the 21st century simulated by HadGEM2-AO under representative concentration pathways. Asia-Pac. J. Atmos. Sci., doi:10.1007/s13143-013-0053-7.

Beck, P. S A., and S. J. Goetz, 2011: Pieter S A Beck and Scott J Goetz. Environ. Res. Lett., 6, doi:10.1088/ 1748-9326/6/4/045501.

Betts, R. A., P. M. Cox, M. Collins, P. P. Harris, C. Huntingford, and C. D. Jones, 2004: The role of ecosystem-atmosphere interactions in simulated Amazonian precipitation decrease and forest dieback under global climate warming. Theor. Appl. Climatol., 78, 157175.

Clarke, L., J. Edmonds, H. Jacoby, H. Pitcher, J. Reilly, and R. Richels, 2007: Scenarios of greenhouse gas emissions and atmospheric concentrations, U.S. Climate Change Science Program and the Subcommittee on Global Change Research Synthesis and Assessment Product 2.1 Sub-Rep. 2.1A.

Collins, W. J., and Coauthors, 2011: Development and evaluation of an Earth-system model-HadGEM2. Geosci. Model Dev., 4, 1051-1075, doi:10.5194/gmd4-1051-2011.

Cox, P. M., 2001: Description of the TRIFFID dynamic global vegetation model. Hadley Centre Tech. Note, 24, 17.

Essery, R., M. Best, R. Betts, P. Cox, and C. Taylor, 2001: Explicit representation of subgrid heterogeneity in a GCM land-surface scheme. Clim. Dynam., submitted.

Fischer, M. L., D. P. Billesbach, J. A. Berry, W. J. Riley, and M. S. Torn, 2007: Spatiotemporal variations in growing season exchanges of $\mathrm{CO} 2, \mathrm{H} 2 \mathrm{O}$, and sensible heat in agricultural fields of the southern great plains. Earth Interact., 11, 1-21, doi:10.1175/EI231.1. 
Good, P., C. Jones, J. Lowe, R. Betts, and B. Booth, 2010: Quantifying environmental drivers of future tropical forest extent. J. Climate, 24, 1337-1349.

Hijioka, Y., Y. Matsuoka, H. Nishimoto, M. Masui, and M. Kainuma, 2008: Global GHG emissions scenarios under GHG concentration stabilization targets. $J$. Global Environ. Eng., 13, 97-108.

Jang, J.-H., K. Hong, Y.-H. Byun, H. J. Kwon, N. M. Chae, J.-H. Lim, and J. Kim, 2010: A sensitivity analysis of JULES land surface model for two major ecosystems in Korea : Influence of biophysical parameters on the simulation of gross primary productivity and ecosystem respiration. Korean J. Agric. Forest Meteor., 12.

Jolly, W. M., M. Dobbertin, N. E. Zimmermann, and M. Reichstein, 2005: Divergent vegetation growth responses to the 2003 heat wave in the Swiss Alps, Geophys. Res. Lett., 32, L18409, doi:10.1029/ 2005 GL023252.

Jones, C. D., and Coauthors, 2011: The HadGEM2-ES implementation of CMIP5 centennial simulations. Geosci. Model Dev., 4, 543-570.

Jones, C., and Coauthors, 2013: Twenty-first-century compatible $\mathrm{CO} 2$ emissions and airborne fraction simulated by CMIP5 earth system models under four epresentative Concentration Pathways. J. Climate, 26, doi:10.1175/JCLI-D-12-00554.1.

Knutti, R., and J. Sedláček, 2013: Robustness and uncertainties in the new CMIP5 climate model projections. Nature Climate Change, 3, 369-373, doi:10.1038/ nclimate 1716.

Liddicoat, S., C. Jones, and E. Robertson, 2013: CO2 emissions determined by HadGEM2-ES to be compatible with the representative concentration pathway scenarios and their extensions. J. Climate, 26, doi:10.1175/ JCLI-D-12-00569.1.

Martin, G. M., and L. C. Levine, 2012: The influence of dynamic vegetation on the present-day simulation and future projections of the South Asian summer monsoon in the HadGEM2 family. Earth Syst. Dynam., 3, 245-261.

Moss, R. H., and Coauthors, 2010: The next generation of scenarios for climate change research and assessment. Nature, 463, 747-756, doi:10.1038/nature08823.

Mynenl, R. B., C. D. Keeling, C. J. Tucker, G. Asrar, and R. R. Nrmmanl, 1997 : Increased plant growth in the northern high latitudes from 1981 to 1991. Nature,
386, 698-702, doi:10.1038/386698a0.

Notaro, M., S. Vavrus, and Z. Liu, 2007: Global vegetation and climate due to future increases in $\mathrm{CO} 2$ as projected by a fully coupled model with dynamic vegetation. J. Climate, 20, 70-90.

Piao, S., X. Wang, P. Ciais, B. Zhu, T. Wang, and J. Liu, 2011: Changes in satellite-derived vegetation growth trend in temperate and boreal Eurasia from 1982 to 2006. Global Change Biol., 17, 3228-3239, doi: 10.1111/j.1365-2486.2011.02419.

Port, U., V. Brovkin, and M. Claussen, 2005: The influence of vegetation dynamics on anthropogenic climate change. Earth Syst. Dynam., 3, 233-243.

Quéré C. Le, and Coauthors, 2013: The global carbon budget 1959-2011. Earth Syst. Sci. Data, 5, 165-185.

Riahi, K., A. Gruebler, and N. Nakicenovic, 2007: Scenarios of longterm socio-economic and environmental development under climate stabilization. Technol. Forecasting Soc. Change, 74, 887-935.

Rogelj, J., M. Meinshausen, and R. Knutti, 2012: Global warming under old and new scenarios using IPCC climate sensitivity range estimates. Nature Climate Change, 2, 248-253, doi:10.1038/nclimate1385.

Shao, P., X. Zeng, K. Sakaguchi, R. K. Monson, and X. Zeng, 2013: Terrestrial carbon cycle - climate relations in eight CMIP5 earth system models. J. Climate, 26, 8744-8764, doi:http://dx.doi.org/10.1175/ JCLI-D-12-00831.1.

Solomon, S., D. Qin, M. Manning, M. Marquis, K. Averyt, M. M. B. Tignor, H. L. Miller, Jr., and Z. Chen, 2007: IPCC AR4 WG II.

Van Vuuren, D. P., M. G. J. den Elzen, P. L. Lucas, B. Eickhout, B. J. Strengers, B. van Ruijven, S. Wonink, and R. van Houdt, 2007: Stabilizing greenhouse gas concentrations at low levels : an assessment of reduction strategies and costs. Climatic Change, 81, 119159, doi:10.1007/s10584-006-9172-9.

$\mathrm{Xu}, \mathrm{C} . \mathrm{-H}$., and Y. Xu, 2012: The projection of temperature and precipitation over china under RCP scenarios using a CMIP5 multi-model ensemble. Atmos.Oceanic Sci. Lett., 5, 527-533.

Zhao, M., and S. W. Running, 2010: Drought-induced reduction in global terrestrial net primary production from 2000 through 2009. Science, 329, 940-943, doi:10.1126/science.1192666. 